DOI: 10.1515/ausp-2015-0057

\title{
Translation in ESL Classes
}

\author{
Imola Katalin NAGY \\ Department of Applied Linguistics, \\ Faculty of Technical and Human Sciences, Târgu Mureş \\ Sapientia Hungarian University of Transylvania \\ nimolkat@gmail.com
}

\begin{abstract}
The problem of translation in foreign language classes cannot be dealt with unless we attempt to make an overview of what translation meant for language teaching in different periods of language pedagogy. From the translation-oriented grammar-translation method through the complete ban on translation and mother tongue during the times of the audio-lingual approaches, we have come today to reconsider the role and status of translation in ESL classes. This article attempts to advocate for translation as a useful ESL class activity, which can completely fulfil the requirements of communicativeness. We also attempt to identify some activities and games, which rely on translation in some books published in the 1990s and the 2000s.
\end{abstract}

Keywords: language teaching, method, translation, communicative and post-communicative language classes

\section{Introduction}

Language and culture are inseparable; hence the teaching of language is always intertwined with the teaching of culture. Linguistic and inter-linguistic communicative competence rely heavily on cultural and intercultural knowledge. Within intercultural knowledge and competence, the process of translation plays an essential role. Translation and teaching translation have been strongly debated issues in the field of foreign language teaching, and today we differentiate professional translation from pedagogic or school translation. The two types of translations, as we shall see, differ widely; what connects them is their capacity to bridge the gap between two cultures.

The attitude towards translation tasks in foreign language classrooms has been different in every major period and approach to language teaching. Adriana Vizental (2008: 30) makes an overview of the main trends in foreign language teaching, distinguishing between several successive generations of approaches: 
- the grammar-translation method (GTM);

- the audio-lingual approaches (ALA);

- the communicative approach (CLT);

- the post-communicative turn (PCT).

Each method displays a different treatment of translation as a classroom activity.

\section{The Grammar-Translation Method}

Translation is a long-standing method in teaching foreign or second languages. Long before Grammar-Translation (GT) methods arose in the $19^{\text {th }}$ century, there had been an emphasis on grammar in language teaching using translation techniques which had been developed in the $16^{\text {th }}$ century. During the reign of the GT paradigm, translation was used to understand and learn grammatical use of the L2 better by providing meaning (mother tongue translation). Rather unnatural L2 sentences, often translated from the learner's first language (L1), were used to introduce the grammatical targets. The methodology, with its focus on learning grammar rules and vocabulary, and deductive L2 learning, did not provide for listening and speaking activities. It also induced a false impression that fixed word to word, or phrase to phrase, translation is possible between L1 and L2 (Machida 2008: 140-141).

According to Vizental (2008), the grammar-translation method, or the classical method, is one of the oldest methods, its principles and techniques being similar to those used for teaching "dead" languages such as Latin or Greek. As its name suggests, the grammar-translation method relies on acquisition of language by learning vocabulary and grammar rules, with translation employed as the main operational technique. One of the most important shortcomings of GTM was learners' inability to cope with actual communicative situations in spite of mastering the grammar of a language.

\section{The Audiolingual Method}

"By mid-20 $0^{\text {th }}$ century, the Audiolingual Method (ALM), based on the Army Specialised Training Program developed during the Second World War, had swept into second language teaching. It exemplified the shift of emphasis in foreign language teaching from written to spoken" (ibid. 141-142). The audio-lingual approaches (ALA) focused on developing oral skills, and considered reading and writing of secondary importance... 
$20^{\text {th }}$ century audio-lingual teachers suggested teaching the foreign language by using it exclusively. No explanation in or translation into the students' native tongue was allowed in their classes: all instructions had to be given in the target language, and meanings were explained with the help of visuals, realia (real objects), paralanguage, and demonstration (Vizental 2008: 31-32).

The audio-lingual method that emerged adopted at least three basic ideas from the direct method:

- the ban imposed on the learner's mother tongue; exclusive usage of the target language for teaching purposes;

- the contextual presentation of vocabulary and grammar;

- the importance given to habit formation (ibid. 33).

Audio-linguists insisted that both vocabulary and grammar should be taught in context. Learning vocabulary in context was extremely important because bilingual lists may give rise to all kinds of mistakes. The audio-linguists' approach to grammar is that - since students generally view grammar as difficult and boring - theoretical presentations should be avoided. Among the basic audiolingual techniques, Vizental mentions the following:

- using commands to direct behaviour, i.e. students perform actions as indicated by the teacher/other students;

- repetition and memorization, to facilitate habit formation;

- drilling, i.e. practising the new vocabulary and grammatical patterns in:

- exercises, e.g. repetition drills, substitution or transformation exercises;

- question-answer (teacher-student or student-student) exchanges, based on the text;

- grammar/vocabulary games;

- conversation practice, role play: i.e. dialogues similar to the text are performed by pairs of students in front of the class, etc. (ibid. 34).

\section{The Communicative Method}

The 1970s witnessed the emergence of the communicative approach to language teaching, which also had several actual teaching models, e.g. the functional-notional approach, the total physical response, the competencybased approach, etc.

The same post-war period saw development of a number of approaches based on or diverging from Chomsky's theories. One of the most significant and enduring was the Communicative approach, which placed emphasis on meaningful input in L2 (exposure to L2 in realistic situations) and a naturalistic approach (like children's L1 learning). As a result, teaching 
explicit linguistic forms and using the mother tongue were avoided. More latterly, the limitations of using a Communicative approach alone have been raised with respect to the teaching or learning of academic or professional language use, and it is charged with not providing opportunities to develop some language knowledge and skills, such as accuracy in language use. Another approach from that time was the notional/functional syllabus, which organized the language to be taught under notional and functional categories and emphasized language as a tool of communication. In place of the word-to-word or linguistic equivalents of other approaches, it promoted teaching a new language through presenting functional equations between the first and second language usage. A key criticism of this approach was that it could give learners the basis from which they could generate their own expressions (Machida 2008: 141-142).

The communicative approach is not a highly structured method, but rather a broad set of ideas generally accepted as good teaching practice. Communicative language teaching relies on the premises that:

1. the ultimate aim of foreign language teaching is to develop the learners' communicative competence: human communication relies on much more than the interlocutors' linguistic competence; fluent speakers are able to interact linguistically thanks to their knowledge of society and of discourses, to their ability to interact spontaneously and cope with a variety of everyday situations;

2. learning begins with imitation; but, unless the learner moves on to the stage of free production, it does not turn into actual, long-term learning: teachers must allow students freedom and encourage their creativity in producing their own language;

3. developing language skills is more important than teaching content:

- the students must be equipped with tools for language performance in the real world; such tools facilitate life-long learning, outside the school system;

- the students must be taught to use the language functionally and strategically, to achieve real-world aims, the way people do in real life;

4. meaning is more important than form; fluency of language is as important as linguistic accuracy; grammar should be taught only when necessary:

- learners must acquire confidence in their linguistic abilities and become less scared of making mistakes; errors are a natural part of learning: as long as the speaker manages to get his/her message through, the teacher should not interfere to correct their mistakes;

- the students must learn the language by using the language, i.e. by struggling to communicate; this way, they learn vocabulary and grammar in context;

5. appropriacy of language is as important as linguistic accuracy:

- communication takes place in a certain social and discoursal background; communicating means establishing relationships between the interlocutors 
(e.g. their respective age, sex, familiarity, roles of speaker/listener); between the speaker and the setting in which the interaction takes place (e.g. place, time, activity type), between the speaker and the type of discourse (e.g. casual conversation or formal debate), etc.;

- the students must be taught to observe social conventions and adapt their language to the requirements of the social and discoursal context, i.e. select their vocabulary and communicative strategies according to the situational context;

6. active participation and affective involvement in the learning process motivate the students and enhance learning:

- the student must become a partner in the learning process, a negotiator between the self, the learning process, and the object of learning; active modes of learning (e.g. pair work, group work) ensure long-term acquisition;

- learners must be able to personalize the topic and relate it to their own lives and interests; this way, the learning material becomes real and meaningful;

7. spontaneous, improvised practice is more efficient than mechanical repetition:

- ordinary communication is spontaneous and unexpected; memorized patterns cannot cover the wide range of real-life situations; the students must be encouraged to use everyday language, typical for ordinary communicative exchanges;

- analysing the needs of language learners in society, communicative teachers concluded that people need primarily oral language skills; however, reading and writing must also be considered;

8. language is a mere medium for communication; communication has a social purpose:

- language must not be taught for its own sake (e.g. for mastering patterns) but for the purpose of sending and receiving messages;

- the learner must be given a purpose for producing language (e.g. exchanging information, approving, or criticizing);

9. communication is basically interactive:

- classroom activities must simulate real-world interactions: the students share and negotiate information, the way people do in real social and discoursal contexts that imitate those in which real communication takes place;

- interactive techniques (e.g. simulation, role play, debate) are efficient procedures for language learning;

10. language learning should be task-oriented: the students must be made to perform tasks with the help of the language, the way people do in the real world;

11. language must be learned with the help of authentic material:

- the textbook is only a framework for the teacher's lesson;

- the teacher must use linguistic material similar to those from real life (e.g. magazine articles, instructions of usage, guidebooks) 
- mother tongue is an important element of the students' world: the students' mother tongue should be used whenever explanations in the target language would be time-consuming; translation is also accepted (Vizental 2008: 35-37).

The typical text of the communicative approach is the authentic material. Since communicative language teaching targets productive and communicative skills, the texts may only provide a framework for subsequent activities, and there must always be an information gap which will trigger exchange and negotiation of meaning in students' interactions. The communicative curriculum no longer focuses on content (i.e. on the lessons to be learned) but on language functions. By emphasizing language functions, communicative teaching becomes competencybased (i.e. learners must show what they can do with the help of the language) and task-oriented (i.e. they are taught to perform practical tasks with the help of the language, in situations that simulate or approximate those encountered in real life) (ibid. 39).

\section{Current post-communicative paradigm}

A number of new approaches to language learning have appeared in recent years. They are called by Vizental the post-communicative turn (PCT), but the terms eclectic method, cognitive method, post method, etc. are introduced by others (Vizental 2008). Although they cannot be described as a unified theory, the new methods show clearly that teachers have analysed the strengths and weaknesses of the previous approaches thoroughly. The post-communicative turn (PCT) views language learning as:

-task-oriented: language learning focuses on meaningand on authentic activities (i.e. activities that approximate those in the outside world); the learners are taught to use the language to construct and communicate meaning;

- context-oriented: language learning is successful if the content to be taught and the context of learning are compatible with the learner's world knowledge and personal experience;

- collaborative: learning is achieved through social interaction and negotiation of meaning;

- cognitive: language learning must go hand in hand with cultural awareness; the students are taught to differentiate between their mother tongue patterns and those of the target culture;

- encourage learner autonomy: learners must control their own learning and construct their own knowledge, they must be aware of the processes and strategies of language learning (ibid. 44).

B. Kumaravadivelu calls this latter trend of language teaching methodology the postmethod condition. "Having witnessed how methods go through endless 
cycles of life, death, and rebirth, the language teaching profession seems to have reached a state of heightened awareness - an awareness that as long as it is caught up in the web of method, it will continue to get entangled in an unending search for an unavailable solution, an awareness that such a search drives it to continually recycle and repackage the same old ideas, and an awareness that nothing short of breaking the cycle can salvage the situation. This renewed awareness coupled with a resolve to respond has created what I have called the postmethod condition” (Kumaravadivelu 2006: 162). Kumaravadivelu prefers to call this period postmethod rather than eclectic as he believes in the (quasinietzschean) idea of the death of the Method, launched by the British applied linguist Dick Allwright, who gave a plenary talk in 1991 at a conference at Carleton University in Ottawa, Canada, a talk entitled The death of the method. The main idea of this talk was the unhelpfulness of the existence of 'methods'.

As Kumaravadivelu puts it, teachers find it difficult to develop a

... valuable, internally-derived sense of coherence about language teaching in part because the transmission model of teacher education they may have undergone does little more than passing on to them a ready-made package of methods and method-related body of knowledge. They find such a method-based teacher education woefully inadequate to meet the challenges of the practice of everyday teaching. [...] In a clear repudiation of established methods and their estranged myths, teachers try to derive a "method" of their own and call it eclectic method.

Constructing a principled eclectic method is not easy. [...] The difficulties faced by teachers in developing an enlightened eclectic method are not hard to find (ibid. 170-171).

As Long states in the Routledge encyclopedia of language teaching and learning (Long 2000: 4), practising teachers end up with some form of eclectic method that is usually little more than an amalgam of their inventors' prejudices. Similarly, Kumaravadivelu concludes that the postmethod condition is

... a sustainable state of affairs that compels us to fundamentally restructure our view of language teaching and teacher education. It urges us to review the character and content of classroom teaching in all its pedagogical and ideological perspectives. It drives us to streamline our teacher education by refiguring the reified relationship between theory and practice. Postmethod pedagogy can be visualized as a three-dimensional system consisting of three pedagogic parameters: particularity, practicality, and possibility. As will become clear, each parameter shapes and is shaped by the others. They interweave and interact with each other in a synergic relationship where the whole is much more than the sum of its parts (Kumaravadivelu 2006: 170-171). 
Many of the principles and techniques of the post-communicative turn have their roots in communicative teaching. Still, the performances of the communicative approach are improved in the following points:

- grammar must be taught thoroughly;

- writing must be practised fully;

- literature must be given its due role.

That is why, according to Adriana Vizental, today's teaching practice skillfully combines techniques and procedures borrowed from previous generations:

- beginners, who basically need acquisition of language, benefit from the techniques of the audio-lingual methods; situational dialogues, pattern practice, repetition and memorization, etc. lead to good linguistic habits;

- at advanced levels, when the students need to develop an ability to deal with the language independently, the grammar-translation method may produce good results - after all, the grammar-translation method is still basic for achieving "high culture"; theoretical presentation of grammar, translation, summarizing, etc. are efficient techniques for independent work;

- communicative activities must be set at all levels, to supplement the performances of the other approaches: the students must be made to develop the text and interact with one another, express thoughts and feelings, negotiate meanings, use the language functionally and strategically; by using authentic material, setting up real-world-like situations, activating the students' personal experience, and involving them emotionally, the teacher creates a positive atmosphere that facilitates learning; communicative activities must be accompanied by efficient error-correction techniques;

- post-communicative teachers rediscovered the value of writing in the formation of the educated person; writing assignments can be task-based (fill out an application form, order a product from a catalogue, find information on the Internet, etc.); however, understanding the modern learner's need to formulate thoughts in writing in a systematic and educated way, post-communicative teachers also returned to non-communicative subjective writing tasks (e.g. the essay) (Vizental 2008: 45).

\section{Translation tasks in foreign language classes}

The question that we try to answer in this study is whether today's foreign language classes should or should not involve translation exercises. The answer to this question seems to have given birth to debates, as the number of studies and articles on this topic shows it. Let us try to summarize some of the main ideas of these contributions. The first and foremost difference should be made between professional and non-professional translation, called pedagogic or school translation. 
Kinga Klaudy separates pedagogical translation from real translation. According to her:

Pedagogical and real translation can be distinguished on the basis of function, object, and addressee. As regards function, in the case of pedagogical translations, translation is a tool, whereas it is the goal of real translations. We can speak of pedagogical translation when the aim of teaching is not the development of translation skills, but the improvement of language proficiency. In such cases, translation tasks serve merely as a means of consciousness-raising, practicing, or testing language knowledge. We can speak of real translation only if the aim of translation is to develop translation skills. The two types of translation can be distinguished on the basis of the object of the translation: while in real translation the translator communicates information about reality, in pedagogical translation the translator provides information about his/her level of proficiency.

And finally, a distinction can be made on the basis of the addressee of the translation: while in real translation the addressee is a reader, who wants information about reality, unsuspecting and well-intended, not set to find mistakes, in pedagogical translation, the addressee is the teacher or examiner, who wants to find out about the language proficiency of the translator and feels compelled to find mistakes.

From all this, it follows that real translator training starts where foreign language teaching ends. In other words, in secondary schools, and even in the foreign language departments of universities and colleges, we may only speak of pedagogical translation, while the teaching of real translation remains the task of translator and interpreter training colleges and postgraduate courses, designed specially for this purpose (Klaudy 2003: 133).

Albert Vermes comes up with an overview of pros and cons of using translation in ESL classes in his article Translation in foreign language teaching: a brief overview of pros and cons (published in Eger Journal of English Studies X (2010): 83-93) The author starts up with the necessity of distinguishing between pedagogical translation and real translation, as suggested by Klaudy (Klaudy 2003: 133).

A discussion of translation pedagogy requires that a distinction be made between two types of translation, which she calls pedagogical translation and real translation. [...] Pedagogical translation is an instrumental kind of translation, in which the translated text serves as a tool of improving the language learner's foreign language proficiency. In real translation, on the other hand, the translated text is not a tool but the very goal of the process (Vermes 2010: 83).

Another scholar referred to by Vermes is Gile (1995), whose distinction between school translation and professional translation is essentially similar 
to that suggested by Klaudy. Gile defines school translation as the writing of texts following lexical and syntactic choices induced by the source-language text, as opposed to professional translation, which is aimed at a reader who is fundamentally interested in the contents of the text (Gile 1995: 22).

In school translation, the focus is on the language, while in professional translation it is on the content of language. Professional translation can thus be seen as a different level of translation, where linguistic problems, in a strict sense, are a mere side issue. Thus the teaching of translation for professional purposes is also qualitatively different from the use of translation in foreign language teaching (Vermes 2010: 84).

All in all, Klaudy's (and Vermes's) taxonomy deals with two kinds of pedagogical translation:

- one serves as a tool of foreign language teaching and

- the other as a tool of translator training.

The object of the first is information about foreign language proficiency, while the object of the second is information about translational proficiency. To distinguish these two subtypes, Vermes uses Gile's term school translation for the first type and he calls the second type simulated translation.

The use of translation for the purposes of language teaching is bound to be associated with the Grammar-Translation Method, which was first employed in the secondary schools of Prussia at the end of the $18^{\text {th }}$ century. The method appeared as a reaction to a social need, as the teaching of modern languages to masses of learners (who) required changes in earlier practices of language teaching. The Grammar-Translation Method was a modified version of the ancient Scholastic Method, which was traditionally used to study the written form of the classical languages through a meticulous lexical and grammatical analysis of classic texts. The first voice to cry out against the use of translation in foreign language teaching came from the Reform Movement of the late $19^{\text {th }}$ century, and it was followed by a wave of renewed attacks by proponents of the Audio-Lingual, the Direct, the Natural, and the Communicative Language Teaching Methods throughout the $20^{\text {th }}$ century (ibid. 85-86).

Malmkjær provides some further general objections to school translation, which are the following (Malmkjær 1998: 5):

Translation is independent of the four skills which define language competence: reading, writing, speaking and listening; it is radically different from the four skills; it takes up valuable time which could be used to teach these four skills; it is unnatural; it misleads students into thinking that expressions in two languages correspond one-to-one; it produces interference; it prevents students from thinking in the foreign language; and it is a bad test for language skills (Malmkjær qtd by Vermes 2010: 87). 
Vermes quotes Lado (1964) who argues against school translation on the following grounds:

(a) There are few, if any, fully equivalent words in two languages. (b) Supposing that the words in the two languages are equivalent, the learner will mistakenly think that the translations can be used in the same situations as the originals. Such overextensions produce interference phenomena in language acquisition. (c) Word-for-word translations result in incorrect constructions (Lado qtd by Vermes 2010: 89).

Heltai's (1996) findings suggest that language learners at the intermediate level are not prepared to do translation in the true sense of the term.

"Their translations are dominated by decoding and encoding processes, and exemplify a kind of semantic translation in which only the referential function of the text is observed. Learners' translations are clearly different from professional translations in this regard."

Vermes reaches the conclusion that:

...there are some good reasons in favour of the inclusion of translation exercises in the foreign language syllabus or, at least, that there are no fundamental reasons for its exclusion. The objections to the use of translation in foreign language teaching are all based on a limited view of translation. But translation is not only structure manipulation; it is primarily a form of communication. And, as such, it necessarily involves interaction and cooperation between people, which makes it a potentially very useful device in foreign language teaching (Vermes 2010: 89).

Sandra J. Savignon also advocates the possibility of implementing translation exercises in a communicative language teaching approach. Disappointment with both grammar-translation and audio-lingual methods for their inability to prepare learners for the interpretation, expression, and negotiation of meaning should not impose a ban on using translation in activities labelled communicative.

Communicative language teaching need not entail complete rejection of familiar materials. Materials designed to promote communicative competence can be used as aids to memorization, repetition, and translation, or for grammar exercises. Similarly, a teacher who has only a grammar-translation manual can certainly teach for communicative competence. What matters is the teacher's understanding of what language learning is and how it happens.... Finally, CLT does not exclude a focus on metalinguistic awareness or knowledge of rules of syntax, discourse, and social appropriateness. Focus on form can be a familiar and welcome component in a learning environment that provides rich opportunity for focus on meaning; but focus on form cannot replace practice in communication (Savignon s.a.: 26-27). 
Sayuki Machida's article, A step forward to using translation to teach a foreign/ second language, presents a progress report on research into using translation as an effective teaching method in a foreign/second language class.

"To be successful, the act of translating requires understanding of the original text, and linguistic and non-linguistic abilities and skills to recreate the original text meaning in another language." Thus, according to Machida:

... in the current post-communicative, cognitive paradigm, translation as a teaching method in the second/foreign language class has the following potential strengths:

- it naturally creates more opportunities for the learners to focus not only on meaning but also on the form of the text;

- working back and forth between L1 and L2 can naturally bring not only explicit attention to the form and meaning of the text, but also discussion on linguistic and non-linguistic forms;

- the act of translating can provide the learners with holistic challenging projects, involving problem-solving, and integrate linguistic, cultural, and pragmatic knowledge beyond communicating using language (Machida 2008).

In Machida's research, feedback from the students and teacher observation have shown a definitely positive attitude towards developing the act of translating as a major method. "To conclude, considering the theoretical potential, positive reception from the students, the actual outcomes and findings from this first implementation, translation as a main teaching methodology is feasible, and appears potentially an effective method for teaching L2" (Machida 2008: 154).

Bantas and Croitoru speak about translation as a profession and didactic translation (Bantas-Croitoru 1999: 94), this latter being similar to Klaudy's pedagogic translation. Didactic translation is viewed as an acquisition method and competence test at the same time. It is part of the inter-linguistic teaching strategy (ibid. 101). Bantas relies his advocacy on H. G. Widdowson (Teaching language as communication, London: OUP, 1979: 101) and H. H. Stern (Issues and options in language teaching, Oxford: OUP, 1992: 279), who stand up, in their work, for the use of translation exercises in inter-lingual teaching strategy, as effective tools of foreign language teaching (Bantas-Croitoru 1999: 95).

The role of translation as a teaching tool grows when coming across pragmatic issues, culture dependency, and topics involved in language teaching.

The approach to translation in an educational context, whereby words and grammatical structures in the source language were replaced with their 'correct' equivalents in the target language, did not fail to leave its mark on the generations of translators regularly subjected to the process. [...] In addition to the part that it played in language teaching methodology, translation fulfilled yet another function for modern European linguists following in the footsteps of de Saussure. Unlike the UK and the USA, for 
many smaller nations in Europe, knowledge of more than one language constitutes a lifeline with the outside world and contrastive studies of modern languages have traditionally been a pursuit of scholarly interest [...]

In addition to studying language as determined by social and geographical factors, linguists have also begun to investigate other factors influencing its use. Now a discipline in its own right, the field of pragmatics is receiving increasing attention among linguists interested in examining the purposes for which sentences are used and the real-world conditions under which they are appropriately uttered... Problems may, for instance, arise when speech acts are transferred in translation: situations such as when we make a complaint or a request, offer an apology, or give a compliment (Anderman 2007: 45-62).

The importance of translation in communicative and post-communicative language classrooms seems to be even more evident when thinking of the huge influence pragmatics played in the emergence of communicative language teaching. When teaching English, one has to pay special attention to matters like indirectness, politeness, speech acts, etc. Teaching the difference between speech acts like How do you do?, What do you do?, What are you doing?, and How are you? may require certain elements of translation into mother tongue, as otherwise students may fail to comprehend that How do you do? has turned, from a pragmatic viewpoint, into a greeting formula rather than an inquiry expecting an answer related to one's well-being.

\section{Translation tasks in textbooks and teaching resources}

Relying on H. G. Widdowson's idea that translation and turning sentences or larger chunks of language from mother tongue to foreign language and vice-versa can contribute to the enrichment of foreign language skills, we have tried to uncover the way in which translation tasks are present in different manuals and language books used by teachers of English (Widdowson 1979). We have selected a number of activities, games, and exercises which appear in the following books: Dókus Tünde, Angol szituációk (2002); Némethné Hock Ildikó, Express English. Angol nyelvkönyv I (1995); Paul Davis, More grammar games: cognitive, affective and movement activities for EFL (1995).

In Paul Davis's More grammar games, we identified the following games relying on a certain amount of translation; we have included them in our corpus:

- Self-generated language

It is a grammar game targeting beginner to elementary students. Here is a script of the game with elements of translation or inter-linguistic shifts and use of mother tongue highlighted. 
1. Ask for a volunteer to tell a story about themselves to the group. It may take a moment for a teller to emerge. The teller may speak in English or in a mixture of mother tongue and English.

2. Ask the teller to take the pile of coloured squares and to put one up where the class can see it after saying each sentence of their story. The coloured square from then on represents that sentence.

3. Sit behind the teller. Ask the teller to begin. After each sentence you repeat it in a form as close to the teller's as possible. You give a helpful counselling reformulation rather than a teacherly correction. When the teller has said three or four sentences, stop them and point to one of the three or four coloured squares. Either the teller or someone in the group repeats the sentence represented by the card you are pointing to. Ask the teller to go on. After two or three more sentences you ask someone to recap from the beginning.

4. When the teller has finished the story, ask students to point to cards they remember and to say what they can bring back to mind. Each student may work from one card only, so there is sharing rather than people with good memories monopolizing.

Variation:

At the beginning of a lesson, divide the class into small groups, and give out copies of the Instructions sheet below, ${ }^{1}$ together with sets of $20-30$ square cards. Leave the room for a good 30 minutes. It's important to resist the temptation to keep popping back. You may want to rewrite the hand-out half in mother tongue and half in English if the class level is very low. It is good to use mixed language texts with beginners.

\section{- A sprinkling of people}

It is a game meant to practise collective nouns and it can be played with upper intermediate or advanced students. Here is a script of the game with elements of translation or inter-linguistic shifts and use of mother tongue highlighted.

1. Tell the students you are going to dictate a list of phrases to them. Ask them to estimate and write down the number of individuals they would expect to find in each collective, e.g. 'a herd of elephants: 10-30'.

$1 \quad$ Instruction sheet

1. Please read these instructions.

2. Choose a leader. The leader will organize your work.

3. Choose a story-teller. The story-teller will tell a personal story or describe a place.

4. Give the coloured squares to the story teller. They produce a sentence and put down a card. The card represents the sentence.

5. The story-teller begins.

6. After two or three sentences, the leader stops the story-teller, points to a sentence card and asks someone to reproduce the sentence. The leader does this after every two to three sentences.

7. Take twenty minutes to tell the story this way. At the end, one person tells the whole story.

8. Everybody writes their version of the story. They have another fifteen minutes to do this. 
A clump of trees / a party of tourists / a gang of terrorists / a unit of freedom fighters / a fleet of ships / a spate of rumours / a troop of monkeys / a gaggle of geese / a squadron of fighter planes / a clutch of eggs / a sea of faces / a pride of lions / a hail of bullets / a pack of wolves / a litter of kittens / a school of dolphins / a flight of steps.

2. Write up the words you reckon may have been misspelt. The students check the meanings with you.

3. Get estimates from round the class of the numbers in typical groups e.g. 'a clump of trees is a lot less than a little wood'.

4. Ask them to identify the five phrases that are the least easy to translate into their mother tongue. They compare phrases.

5. Explain that in English you sometimes have a choice of collective nouns. Tell them you will read out pairs of phrases - they are to take down the one they prefer in each pair. Read each pair of phrases twice:

$\begin{array}{ll}\text { a flock of birds } & \text { a flight of birds } \\ \text { a swarm of insects } & \text { a colony of insects } \\ \text { a herd of goats } & \text { a flock of goats } \\ \text { a troupe of actors } & \text { a company of actors } \\ \text { a wad of banknotes } & \text { a roll of banknotes } \\ \text { a pack of cards } & \text { a deck of cards } \\ \text { a team of experts } & \text { a panel of experts } \\ \text { a bunch of grapes } & \text { a cluster of grapes } \\ \text { a sheaf of papers } & \text { a bundle of papers } \\ \text { a crowd of reporters } & \text { a gaggle of reporters } \\ \text { a gang of thieves } & \text { a pack of thieves }\end{array}$

Write up any words they are unsure how to spell, e.g. 'troupe' rather than 'troop'. Group them in threes to explain their choices of phrase. Now pair the students and give out the Collective phrase questionnaire. ${ }^{2}$ Ask the students to work through it, each answering each of the questions.

2 COLLECTIVE PHRASE QUESTIONNAIRE

- Have you ever been in a party of tourists? How many of you were there?

- Can you think of a clump of trees near your house? Roughly how many trees?

Have you ever seen a shoal of fish? Where? What time of the day was it?

- What do you call a big group of bees on the wing? When did you last see a swarm of bees?

- What do you feel on seeing a litter of new-born puppies?

- When did you last carry round a wad of banknotes? Do you often do this? How do you feel if it is a really thick roll?

- Have you ever baked a cake? Have you ever baked a batch of cakes or tarts?

- I bet you have a bunch of keys in your bag/pocket. How many in the bunch?

Is there a flight of steps near your home? How long would it / does it take you to get up them? How many steps are there, approximately?

- How many cards are there in a deck of cards? Are there any special cards in your country with a different number in the pack? 
- Haves and have-nots

It is a game which involves dictation and addresses intermediate students. Here is a script of the game with elements of translation or inter-linguistic shifts and use of mother tongue highlighted.

1 Give out a copy of Haves and have-nots worksheet to each student. Alternatively, you could get the students to make the worksheet. Tell them to turn their pages longways and rule four columns with the following headings:

(1) I smell/I taste (2) I hear (3) I see (4) Feel through my body

2. Tell the students you are going to dictate short sentences to them. Ask them to experience these as situations. If they first hear the situation, they write it in column two. If they first feel the situation, they write it in column four, etc. Many people will see, hear, and feel many of the situations. The choice of column is governed by which of these things they actually do first - what pops up first from the unconscious.

3. Dictate each sentence/phrase twice, ${ }^{3}$ leaving time for students to conjure up the situations.

4. Put the students in threes and ask them to compare where they put the sentences. Ask them to share some of the situations they smelled, heard, saw, or felt.

5. Ask them to go back over the sentences and decide which, when translated into their mother tongue, would not have the equivalent of the verb 'to have' in them. (In Italian, you make a dream and in both Greek and Japanese you see a dream.)

- The world of take

It is a game for intermediate students. Here is a script of the game with elements of translation or inter-linguistic shifts and use of mother tongue highlighted.

1. Put the students in small groups to brainstorm all the uses of the verb take they can think of.

When did you last give someone a bouquet of flowers? Or receive a bunch of flowers?

- What would you mean if you said that most of the audience in the theatre were Japanese but that there was also a sprinkling of French?

3 Dictation sentences for Haves and have nots

I have a headache.

I went to hospital and had a baby.

I have it in me to do great things.

I had a good breakfast.

She had it off with him.

Children love to have stories read to them.

She had some money stolen.

I had a dream last night.

I had my head down.

I had a small operation on my nose.

He hates him he really has it in for him.

The police had me up for speeding.

We had the grass cut.

I have two very good friends. 
2. Ask each group to send a messenger to the next group to pass on their ideas.

3. Dictate the sentences below, ${ }^{4}$ which they are to write down in their mother tongue. Tell them only to write in mother tongue, not English. Be ready to help explain any sentences that students do not understand.

4. Ask the students to work in threes and compare their translations. Go round helping and checking. If your students do not share the same mother tongue, group students from the same language or language groups. In this sort of class, you will probably have three or four people from unrelated languages working together as well. They will learn a lot about each other's languages from this exercise.

The rationale of this game is that students come to see how similar and how different the grammars of mother tongue and of foreign languages actually are. As the author, Paul Davis, puts it, this game is "a gem of a translation exercise, as you have the author of what you are translating there at your elbow. You are translating within a living relationship and you are a protagonist rather than a third party, as is the case in an interpreting situation” (Davis 1995).

Another type of exercise involving translation is the mixed language conversation. Dókus Tünde’s book, Angol szituációk, provides a whole array of situations, model conversations, and mixed language conversations which can be adapted for a communicative language classroom. A conversation like the one below can be used in pairs, in small groups; it can be cut into halves, then reconstructed and acted out; it can be used even as a lockstep activity (the teacher dictates the sentences in mother tongue; when role-playing it, the students have to translate their replies on the spot), etc. An introductory description of the situation may be provided not only in mother tongue (as in this example provided here) but also in English.

Ön nagyon rosszul érzi magát, ezért felhívja külföldi barátját, hogy lemondja az esti vacsorameghívást. Kérjen elnézést, és mondja el, hogy mik a panaszai. Fogadja el a felajánlott segítséget.

4 Dictation sentences for The world of take

The new president took over in January.

The man took the woman's anger seriously.

'You haven't done the washing up, I take it,' his wife said to him.

The little boy took the old watch apart to see how it worked.

'I think we ought to take the car,' he said to her.

This bloke always takes his problems to his mother.

'We took the village without a shot being fired,' she told him.

'Take care,' the woman said, as she left home that morning.

He took charge of the planning team.

The woman asked what size shoes he took.

'Yes, I really take your point,' he told her.

'If we go to a movie,' she told her boyfriend, 'it'll really take you out of yourself.'

The news the boy brought really took the woman aback.

The chair asked him to take the minutes of the meeting.

'You can take it from me, it's worse than you think.' 
Szia, Dániel! Laci vagyok.

Hello, Laci! I just wanted to call you to say that the reservation is okay. We have a table for two at seven.

Pont ezért telefonálok. Sajnos, semmiképpen sem tudok menni. Nem tudom, mi történt, de borzalmasan érzem magam.

That sounds terrible! I hope it's not too bad. What's the problem?

Rettentôen fáj a gyomrom. Lehet, hogy attól a gulyástól, amit ebédre ettem. Nem vagyok hozzászokva a nehéz ételekhez.

Are you sure you can't come? You might feel better by seven.

Nem hiszem. Fel sem tudok kelni. Amint felállok, rögtön elkezdek szédulni. Then I think you should see a doctor. Or better still, I will call my doctor and ask her to have a look at you.

Azt hiszem, tényleg jó lenne, ha kihívnád az orvost.

I think you need looking after. You know what, I will come over to you and make you something to eat.

Nagyon kedves tóled, de egy falatot sem tudnék lenyelni. Hányingerem van, ha ételre gondolok. De ha átjössz, talán jobban fogom magam érezni. All right! See you later! (Dókus 2002)

Némethné Hock Ildikó's Express English provides a long list of simulations and role plays; most of them being in mother tongue, students are asked to perform the conversation in English (Hock 1995).

- Angol ismerôse Magyarországon szeretne letelepedni. Javasolja neki, hogy ne egy nagyvárosban, hanem vidéken vegyen házat. Írja le részletesen a vidéki élet elönyeit. Miközben ismerôse a városi élet pozitív oldalait emeli ki, mondja el neki, hogy vidéken is jó az ellátás. Minden kényelem megvan, kocsival pedig nincs messze a város, a színház, a nagyobb áruházak.

- Hívja meg a barátját egy színházi elóadásra! Mondja el, hogy ez egy nagyon híres darab, és bár az előadás csak egy hét múlva lesz, már most meg kell venni a jegyeket, mert hátha elfogynak. Ismerốse a páholyba szeretne ülni, de Ön úgy gondolja, hogy oda túl drága egy jegy. Döntsék el, hogy végül is hova fogják kérni a jegyet és melyik elóadásra mennek el.

- Ön elmegy az orvoshoz, mert nagyon fáj a karja. Az orvos érdeklödésére elmondja, hogy már egy hete érzi a fájdalmat és akkor a legrosszabb, amikor reggel felkel. De tulajdonképpen egész nap fáj és gyakran a munkát is abba kell hagynia, hogy pihenjen. Próbált már kenöcsöt is tenni rá, de az sem segített.

Sentence level translation can be used especially in the case of passive voice, where the following types of model sentences can be used in the presentation and the practice stages of grammar lessons. Nevertheless, this does not mean that the production phase cannot rely on translation tasks as well, only that they should be embedded in more communicative tasks or they should be made communicative by the use of information gap and interaction. 
He is not often invited to parties. Nem hívják meg gyakran bulikba.

When was this house built? Mikor épült ez a ház?

Who was this novel written by? Ki írta ezt a regényt?

The Prime Minister has been shot. A miniszterelnököt lelótték.

I can't work. My office is being cleaned. Nem tudok dolgozni. Takarítják az irodámat.

I turned round and saw that I was being followed. Amikor megfordultam, láttam, hogy követnek.

All these books were published in Britain. Ezeket a könyveket mind NagyBritanniában adták ki.

The Tower can be found in London. A Tower Londonban található.

Her blood pressure must be checked regularly. A vérnyomását rendszeresen ellenörizni kell.

300 copies of this magazine have to be sold. 300 példányt el kell adni ebból a folyóiratból.

Homework should be done properly. A házi feladatot jól kellene megcsinálni.

The flowers needn't be watered. A virágokat nem kell megöntözni.

You may be asked silly questions. Lehet, hogy buta kérdéseket kapsz.

You are going to be watched. Figyelni fognak.

If you didn't help me, the house would never be sold. Ha te nem segítenél, ez a ház sohasem lenne eladva. ${ }^{5}$

\section{Conclusions}

We can conclude that, after being neglected in the times of audio-lingual methods, translation started to be reintroduced in foreign language classes in the decades of communicative and post-communicative language teaching. What is important with translation tasks in communicative and/or post-communicative language classrooms is that they should always be integrated within a communicative activity. As Widdowson puts it:

...the incorporation of translation into these procedures [of language teaching] ensures that it is carried out as a communicative activity. Their purpose is to make clear to the learner just what is involved in such an activity by relating it to his own experience of language. Translation here is an operation on language use and not simply on language usage and aims at making the learner aware of the communicative value of the language he is learning by overt reference to the communicative functioning of his own language (Widdowson 1979: 160). 
Sentences like the ones above can be used as a starting point for a dialogue; they can be used as first or last sentences of a story (both oral and written). Translation can be integrated into dialogues, pair work, or group work activities. The sentences used for translation should also be as real-life-like as possible; sentence level and text level translation - even when focusing on a certain grammar item - should replicate a real world situation or reply and they should always be personalized so as to fit students' daily linguistic encounters. There are plenty of teaching materials and resources at language teachers' disposal; it is up to them to use these materials in their classes by transforming them into communicative activities rather than using boring and mechanical translation exercises. Since translation is a universally useful activity, which has the power and capacity to bridge the gaps between cultures, we daresay it is a skill whose development should also be incorporated in today's teaching activities, alongside the other four language skills. The key element of today's foreign language teaching is real-life-like communication, situations, speech acts, and language functions that replicate real world situations and contexts. Integrating translation tasks in such real life communication may maximize students' foreign language skills by implementing in classroom activities what happens in real life: as translation happens in the minds of foreign language learners, no matter we admit it or not.

\section{References}

Anderman, Gunilla. 2007. Linguistics and translation. In: Kuhiwczak, PiotrLittau, Karin (eds), A companion to translation studies. Clevedon - Buffalo - Toronto: Multilingual Matters Ltd. 45-62.

Bantas, Andrei-Croitoru, Elena. 1999. Didactica traducerii. Bucureşti: Teora.

Gile, D. 1995. Basic concepts and models for interpreter and translator training. Amsterdam and Philadelphia: John Benjamins.

Davis, Paul. 1995. More grammar games: cognitive, affective and movement activities for EFL. Cambridge: Cambridge University Press.

Dókus, Tünde. 2002. Angol szituációk. Székesfehérvár: Lexika Kiadó.

Klaudy, K. 2003. Languages in translation. Budapest: Scholastica.

Kumaravadivelu, B. 2006. Understanding language teaching. From method to postmethod. San Jose State University. New Jersey London: Lawrence Erlbaum Associates Publishers Mahwah. https://livelongday.files.wordpress. com/2011/08/kumaraposmethod.pdf

Lado, R. 1964. Language Teaching: A Scientific Approach. New York: McGrawHill.

Long, M. H. 2000. Acquisition and teaching. In: Byram, M. (ed.), Encyclopedia of language teaching. London: Routledge. pp. 4-5. 
Machida, Sayuki. 2008. A step forward to using translation to teach a foreign/ second language. Electronic Journal of Foreign Language Teaching 5(Suppl. 1): 140-155. (downloaded on: July the $1^{\text {st }}, 2015$ from http://e-flt.nus.edu.sg/ v5sp12008/machida.pdf).

Malmkjær, K. (ed.). 1998. Translation and language teaching: language teaching and translation. Manchester: St. Jerome Publishing.

Némethné,HockIldikó. 1995. Express English. Angol nyelvkönyvI. Székesfehérvár: Lexika Kiadó.

Savignon, Sandra J. Communicative language teaching: linguistic theory and classroom practice. http://yalepress.yale.edu/excerpts/0300091567_1.pdf.

Vermes, Albert. 2010. Translation in foreign language teaching: a brief overview of pros and cons. In: Eger Journal of English Studies X: 83-93.

Vizental, Adriana. 2008. Metodica predării limbii engleze. Strategies of teaching and testing English as a foreign language. Iaşi: Polirom.

Widdowson, H. G. 1979. Teaching language as communication. London: Oxford University Press. 